\title{
El gran desafío de la latencia de SARS-CoV-2: el testículo como reservorio
}

\author{
Ricardo López-Romero, ${ }^{1}$ María de Jesús Nambo-Lucio, ${ }^{1}$ Emmanuel Salcedo-Carrillo, ${ }^{1}$ \\ María de los Ángeles Hernández-Cueto ${ }^{2}$ y Mauricio Salcedo-Vargas ${ }^{1 *}$ \\ ${ }^{1}$ Centro Médico Nacional Siglo XXI, Hospital de Oncología; ${ }^{2}$ Centro Médico Nacional La Raza, División de Laboratorios de Vigilancia e Investigación \\ Epidemiológica. Instituto Mexicano del Seguro Social, Ciudad de México, México
}

\section{Resumen}

En el afán por explicar la fisiopatogenia de COVID-19 se están realizando estudios en torno a la correspondencia entre la expresión de receptores celulares de SARS-CoV-2 y las secuencias virales. La expresión de los receptores ACE2, CD147 y TMPRSS2 podría indicar blancos de infección poco explorados. Para el análisis genómico de los receptores de SARS-CoV-2 se optó por utilizar la información del BioGPS, un portal que centraliza los recursos de anotación genética, en combinación con la de The Human Protein Atlas, el portal más grande de datos del transcriptoma y proteoma humanos. También se revisaron los artículos más recientemente respecto al tema. En numerosos sitios anatómicos se observó la expresión de ARN y proteínas de los receptores del virus, que coinciden parcialmente con la información reportada en la literatura. Resaltó la alta expresión en las células de los testículos, por lo que sería importante descartar si este sitio anatómico es un reservorio de SARS-CoV-2; de no ser así, determinar el daño en las células germinales, tal como sucede en infecciones por otros virus $A R N$.

PALABRAS CLAVE: SARS. COVID-19. Receptores celulares de SARS-CoV-2. Virus ARN.

\section{The big challenge of SARS-CoV-2 latency: testes as reservoir}

\begin{abstract}
In the efforts to explain COVID-19 pathophysiology, studies are being carried out on the correspondence between the expression of SARS-CoV-2 cell receptors and viral sequences. ACE2, CD147 and TMPRSS2 receptors expression could indicate poorly explored potential infection targets. For the genomic analysis of SARS-CoV-2 receptors, using BioGPS information was decided, which is a portal that centralizes genetic annotation resources, in combination with that of The Human Protein Atlas, the largest portal of human transcriptome and proteome data. We also reviewed the most recent articles on the subject. RNA and viral receptor proteins expression was observed in numerous anatomical sites, which partially coincides with the information reported in the literature. High expression in testicular cells markedly stood out, and it would be therefore important ruling out whether this anatomical site is a SARS-CoV-2 reservoir; otherwise, germ cell damage, as it is observed in infections with other RNA viruses, should be determined.
\end{abstract}

KEY WORDS: SARS. COVID-19. SARS-COV-2 cell receptors. RNA virus.

Correspondencia:

${ }^{*}$ Mauricio Salcedo-Vargas

E-mail: masava89@gmail.com
Fecha de recepción: 15-05-202

Fecha de aceptación: 02-06-2020

DOI: $10.24875 / G M M .20000295$
Gac Med Mex. 2020;156:328-333

Disponible en PubMed

www.gacetamedicademexico.com

0016-3813/@ 2020 Academia Nacional de Medicina de México, A.C. Publicado por Permanyer. Este es un artículo open access bajo la licencia CC BY-NC-ND (http://creativecommons.org/licenses/by-nc-nd/4.0/). 


\section{Introducción}

En diciembre de 2019, en Wuhan, China, emergió un tipo de neumonía asociada a un nuevo coronavirus que provoca síndrome respiratorio agudo severo, al cual se denominó SARS-CoV-2. Para mayo de 2020 se habían generado más de 7000 publicaciones, entre ellas más de 150 artículos sobre aspectos moleculares (según el National Center for Biotechnology Information de Estados Unidos), ${ }^{2}$ lo cual muestra una clara interacción entre la clínica y la investigación biomédica para buscar posibles soluciones al problema de salud que representa la pandemia ocasionada por ese virus.

SARS-CoV-2 es un betacoronavirus que infecta a células epiteliales de humanos y vertebrados, presenta un ARN monocatenario positivo de aproximadamente 29900 bases nucleotídicas cubierto por una membrana lipídica, con más de $80 \%$ de similitud genómica con SARS-CoV-1. ${ }^{3}$ Además, muestra semejanzas con las secuencias de los coronavirus que infectan al murciélago y al pangolín, así como con las del virus de la inmunodeficiencia humana; en otras palabras, se trata de un virus quimera de evolución natural divergente. ${ }^{4,5}$ Se conoce que estos virus codifican para 23 proteínas, entre las cuales las más estudiadas son la proteína estructural N (nucleocápside), la $S$ (espícula, crucial para su entrada a la célula, virulencia y tropismo), la $\mathrm{M}$ (membranal) y la de envoltura. ${ }^{6}$

\section{Utilidad de las mutaciones de SARS-CoV-2 y su complejidad transcripcional}

Al igual que otros virus ARN, la tasa de mutaciones de SARS-CoV-2 es alta, lo cual representa un verdadero reto para el desarrollo de vacunas y se relaciona con los cuadros clínicos graves y las diferencias geográficas. Por ejemplo, se ha reportado que la tasa de mortalidad es distinta en China (5.6\%) y fuera de ese país (15.2\%), lo que podría atribuirse a las diferencias genómicas combinadas con otros factores como las estrategias de aislamiento y la inmunidad de rebaño. ${ }^{7}$

El virus muta para adaptarse al hospedero y de esta manera evoluciona. Se han identificado 13 variaciones en el genoma contenidas en las regiones ORF (open reading frame) 8 , ORF1ab, S, ORF3a y N; las posiciones 28144 (ORF8) y 8782 (ORF1a) presentan tasas de mutación de 30.53 y $29.47 \%$, respectivamente. ${ }^{8}$ Las ARN-polimerasas dependientes de ARN, en especial en la posición 14408 , se asocian a la aparición de fenotipos virales emergentes multirresistentes. ${ }^{9}$ Conocer las mutaciones permitirá desarrollar fármacos dirigidos, como favipiravir, remdesivir, ribavirina para otras enfermedades ocasionadas por virus ARN. ${ }^{10}$

La arquitectura funcional de SARS-CoV-2 es extremadamente compleja. Se sugiere que los ORF de este virus podrían servir como proteínas accesorias para modular la replicación viral. La transcripción discontinua proveniente de su transcriptoma y epitranscriptoma genera nuevas fusiones genómicas, provocando más de 40 modificaciones que contribuyen a su patogenicidad, ciclo viral, evasión exitosa de la respuesta inmune del hospedero y supervivencia. ${ }^{9}$

\section{Primer blanco de infección de SARS-CoV-2 y las pruebas de detección}

Se ha reportado que los principales blancos de infección de SARS-CoV-2 son las células epiteliales del tracto nasofaríngeo. ${ }^{1}$ Por ello, la técnica aprobada para el diagnóstico molecular de este virus es la estimación de la carga viral mediante reacción en cadena de la polimerasa (PCR, polymerase chain reaction) a partir de una muestra del tracto nasofaríngeo (también puede obtenerse de heces fecales o sangre) obtenida con técnica de hisopado, según el protocolo de Berlín publicado el 17 de enero de 2020.11 Este tipo de pruebas, si bien son "rápidas", requieren tiempo, ya que es esencial la purificación del ARN viral y el intervalo para el diagnóstico es de por lo menos ocho horas. A la fecha, la Food and Drug Administration de Estados Unidos ha aprobado diversas pruebas moleculares. ${ }^{12}$

Por otro lado, existen pruebas serológicas más rápidas que detectan alta concentración de anticuerpos IgG e IgM; desafortunadamente, la mayoría presenta baja sensibilidad y especificidad. Ya que la sintomatología de COVID-19 es similar a la de otras enfermedades respiratorias, es indispensable descartar las infecciones por otros virus ARN.

La aplicación de pruebas diagnósticas y los datos clínicos permiten identificar los casos tempranos, los tardíos y los convalecientes o recuperados. Especialmente en los casos tempranos se debe estimar la carga viral, además de aplicar una segunda prueba para definir la probabilidad de infección comunitaria. Una vez que transcurre el periodo de ventana, se intensifica la producción de anticuerpos (aproximadamente en la segunda semana) y se pueden llevar a cabo pruebas serológicas para el control de la enfermedad. ${ }^{13-15}$ 


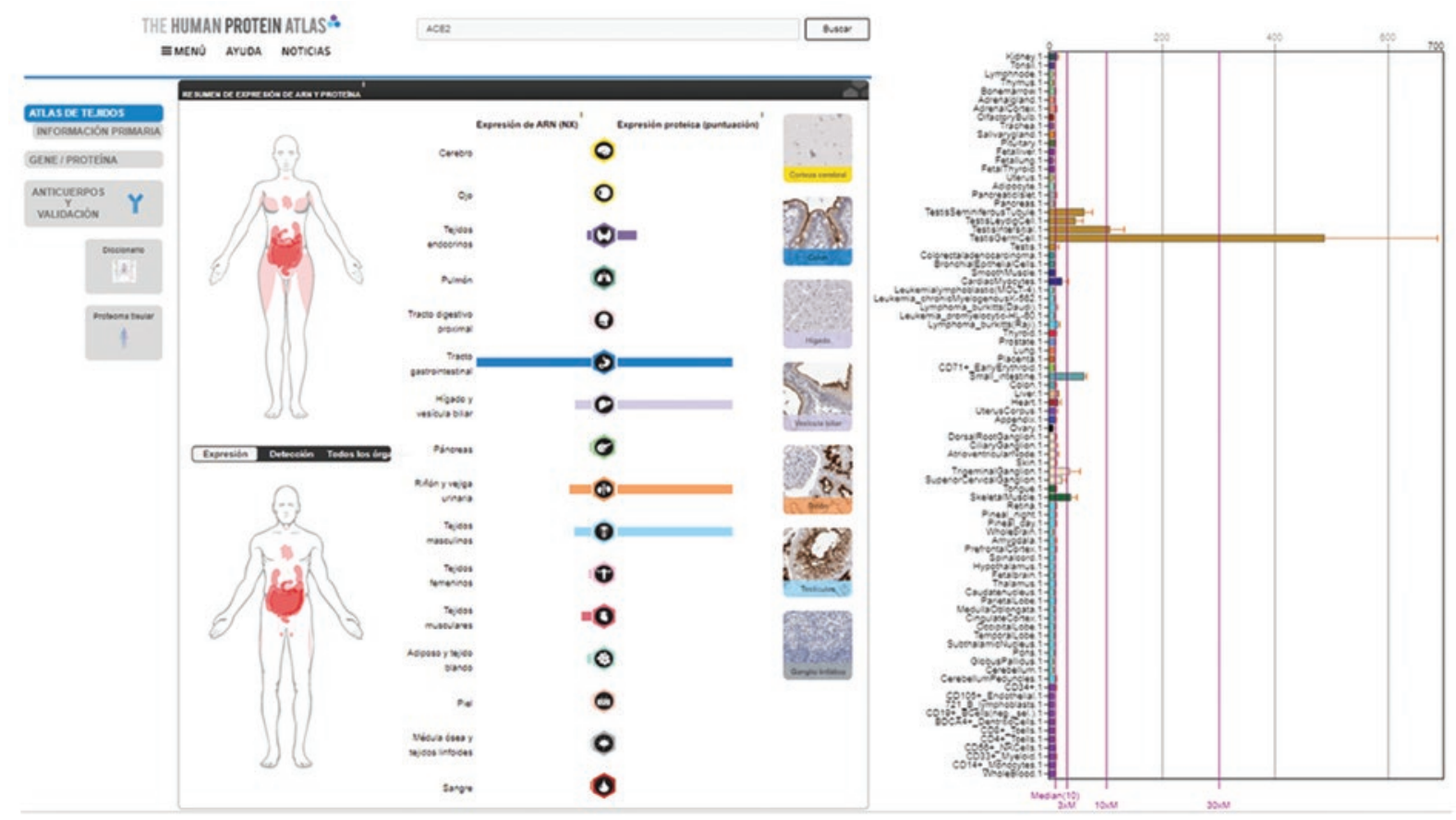

Figura 1. Sitios anatómicos de expresión de la proteína ACE2 que constituyen potenciales blancos de interacción con SARS-CoV-2 en cada sexo. Los iconos indican los sitios anatómicos de la expresión de ARN y la expresión de la proteína. También se ejemplifica la expresión de ACE2 en los tejidos mediante inmunohistoquímica. La gráfica de barras de la derecha muestra la expresión relativa en diferentes tipos de células y se resalta la sobreexpresión en células de testículo (barras de color ocre). Fuente: The Human Protein Atlas.

\section{Proteínas celulares como receptores para la entrada del virus al hospedero}

Las evidencias indican que los blancos moleculares de SARS-CoV-2 son las células que expresan la enzima convertidora de la angiotensina 2 (ACE2, Figura 1) -involucrada en la disminución de la presión arterial al catalizar la escisión de angiotensina II en angiotensina- ${ }^{16}$ la molécula de membrana CD147 ${ }^{17}$ (Figura 2) -que estimula a los fibroblastos para la producción de metaloproteinasas de la matriz y que está asociada a la espermatogénesis y la implantación del embrión- y la serina proteasa TMPRSS2 (Figura 3), regulada por las hormonas androgénicas, entre otras proteínas. ${ }^{18}$ El receptor más estudiado es ACE2, que funciona como receptor de las glucoproteínas de la espiga del virus. ${ }^{19}$ Los datos anteriores sugieren tropismo de SARS-CoV-2 hacia las células que expresan sus proteínas celulares blanco.

\section{Información de bases de datos accesibles}

Se realizó la búsqueda en diferentes bases de datos para determinar otros blancos potenciales de infección. Se eligió The Human Protein Atlas, ${ }^{20}$ en el que se mapean todas las proteínas humanas en células, tejidos y órganos mediante la integración de resultados experimentales obtenidos a partir de diversas herramientas genómicas e histológicas; así como el BioGPS, que conjunta la información relativa a la expresión genética en los diferentes sitios del cuerpo humano. ${ }^{21}$ En un análisis in silico se observó la expresión de ACE2 y CD147 en diversos sitios anatómicos (Figuras 1 a 3); ACE2 se observó en células epiteliales del tracto respiratorio. ${ }^{18-22}$

\section{Expresión de receptores en células específicas: los testículos}

Un estudio reciente demostró que la expresión de ACE2 es mayor en una pequeña población de células alveolares tipo II, las cuales están involucradas con el cuadro de neumonía; también se observó alteración de las células mononucleares, pequeños vasos trombosados, activación de megacariocitos y agregados plaquetarios. ${ }^{23}$ Otras investigaciones muestran que el deterioro es general e involucra también al sistema urinario, ${ }^{24}$ al mecanismo neurotrópico del sistema nervioso central ${ }^{25} \mathrm{y}$ a los enterocitos, ${ }^{26}$ lo que evidencia que esas células poseen genomas virales 

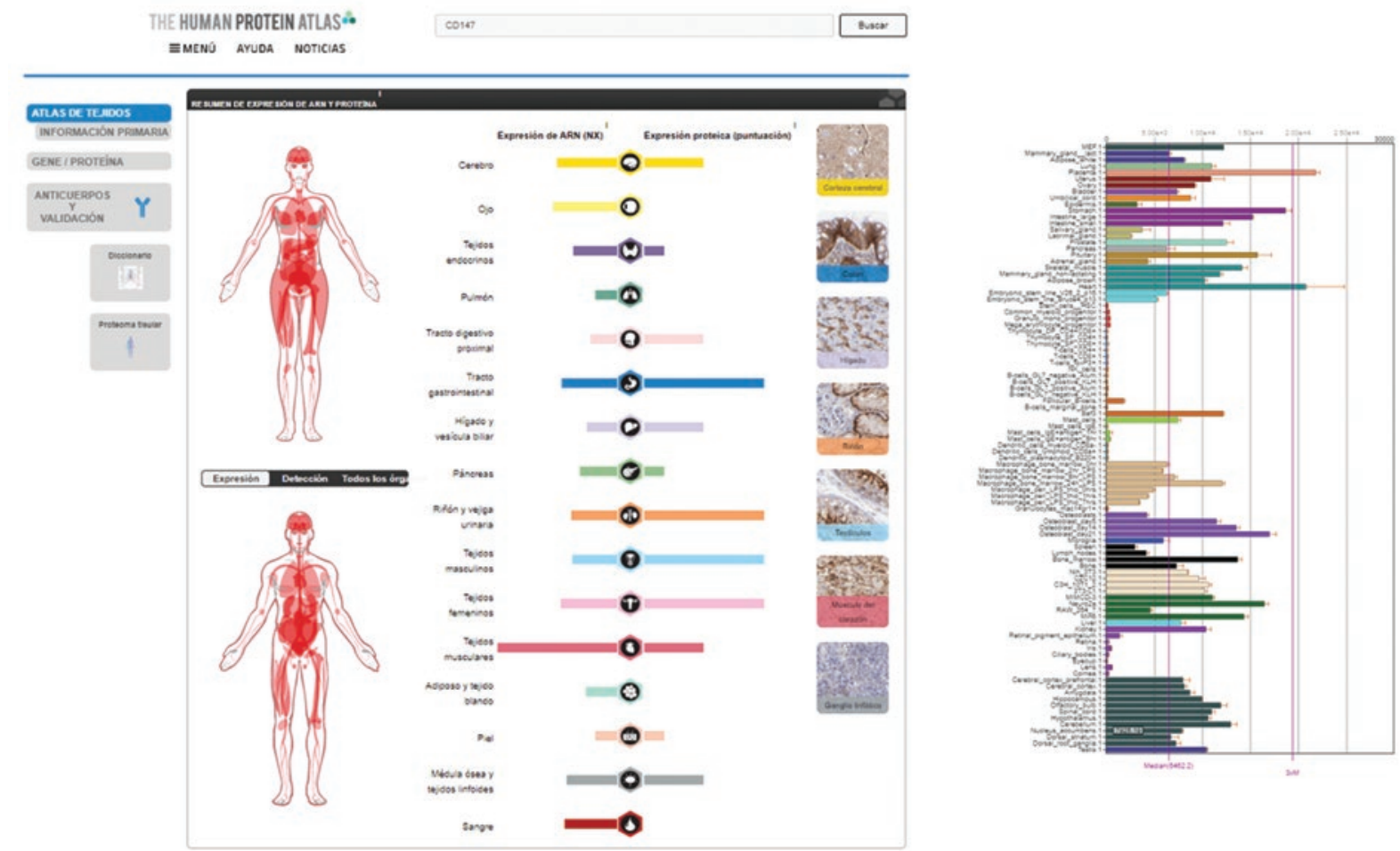

Figura 2. Sitios anatómicos de expresión de CD147 que representan potenciales blancos de interacción con el virus SARS-CoV-2. La gráfica de barras de la derecha muestra la expresión relativa de diferentes tipos de células en la mayor parte del cuerpo. Fuente: The Human Protein Atlas.

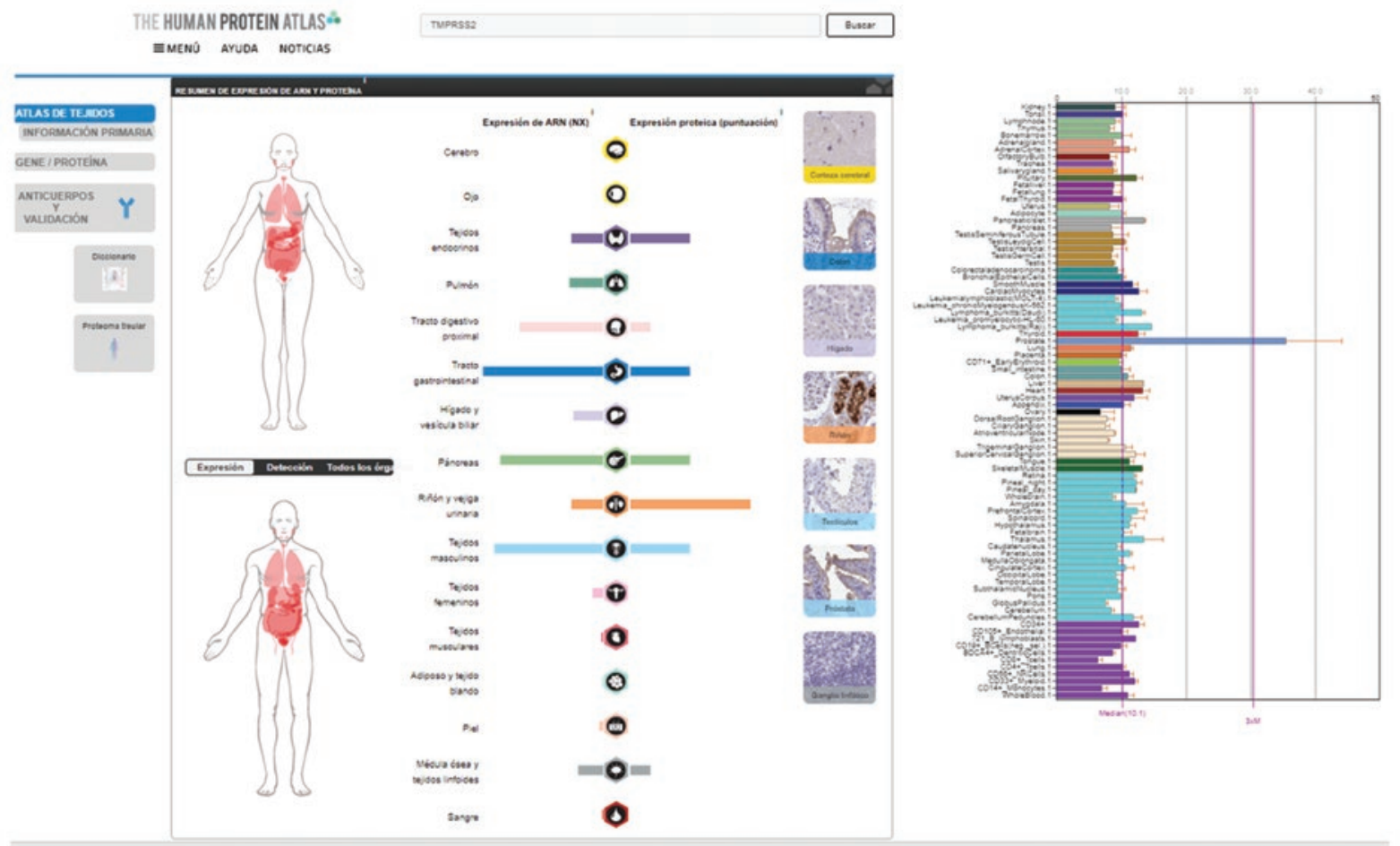

Figura 3. Sitios anatómicos de expresión de la proteína celular TMPRSS2 como potenciales blanco de interacción con el virus SARS-CoV-2. La gráfica de barras de la derecha muestra la expresión relativa de diferentes tipos de células en gran parte del cuerpo y se resalta la mayor expresión en próstata (barra color azul).). Fuente: The Human Protein Atlas. 
y expresan los receptores mencionados. Aunado a lo anterior, la expresión de CD147 muestra que numerosos órganos y tejidos podrían ser susceptibles a la infección por SARS-CoV-2. Llama la atención la alta expresión de estas proteínas celulares en los testículos. No se detectaron secuencias virales en el único reporte sobre búsqueda de SARS-CoV-2 en testículos analizados en autopsias; sin embargo, cabe señalar que la búsqueda fue realizada mediante hibridación in situ, técnica no comparable con la PCR. ${ }^{27}$

\section{Similitudes de SARS-CoV-2 y su latencia con otros virus ARN}

La infección por el virus ARN de la parotiditis (paperas) es muy similar a la de COVID-19: afecta a las células epiteliales (donde se incrementa la carga viral y provoca la viremia), se transmite por gotitas de saliva del portador, ya sea por contacto directo o indirecto con fómites y biofluidos, y muestra tropismo hacia las células de glándulas salivales, del sistema nervioso central, testículos y ovarios; una secuela de la parotiditis es la orquitis, que se relaciona con esterilidad. ${ }^{28}$

Por lo anterior, cabe preguntarse si los síntomas prodrómicos de la influenza, de otras enfermedades respiratorias (como la parotiditis) y los de la infección por SARS-CoV-2 son solo una coincidencia. En este contexto podría correlacionarse la alta expresión de ACE2 en los testículos con la latencia de la infección por SARS-CoV-2, sin embargo, no existe evidencia clara sobre esta asociación. Por ello, consideramos la necesidad de investigar la expresión de ACE2 en tejido testicular que provenga de las autopsias de individuos que fallecen a causa de COVID, así como la detección de secuencias de SARS-CoV-2 mediante PCR, para determinar si existió infección crónica o latente. Una secuela de las infecciones virales (virus ADN y ARN) es la latencia, tal como sucede en la hepatitis ${ }^{29}$ y el herpes. ${ }^{30}$ En pacientes con COVID-19 que no manifestaron síntomas no se identificó ARN viral con pruebas comerciales realizadas durante el seguimiento (más de cuatro semanas); ${ }^{31}$ sin embargo, con tecnología Sherlock, cuyo límite de detección es de 100 copias/mL, en muestras nasales y anales se obtuvo $75 \%$ de resultados positivos para el gen S y $41.6 \%$ para los genes ORF. ${ }^{32}$

Los datos referidos indican la persistencia de las secuencias de SARS-CoV-2 por al menos dos meses en los tractos respiratorio y digestivo (infección latente) y que el hisopado anal puede ser otra prueba de seguimiento. De ahí la importancia de innovar y combinar recursos clínicos y moleculares más sensibles y específicos, para descartar en lo posible los resultados falsos positivos y falsos negativos. ${ }^{33}$ Hasta el momento es insuficiente la información en torno a la infección latente por SARSCoV- $2^{34}$ y sus consecuencias.

Sería deseable que los pacientes recuperados de COVID-19, así como el personal de terapia intensiva y resucitación cardiopulmonar (sin historial de parotiditis) que interactúa directamente con los individuos con infección por SARS-CoV-2 pudieran realizarse estudios moleculares (entre ellos, espermatobioscopia), para descartar daño en las espermatogonias y ausencia de infección latente. Por ello, resulta urgente disponer de más evidencia relativa al tema. Durante la escritura del presente documento se publicó un reporte en ese sentido. ${ }^{35}$

\section{Conclusiones}

Dadas las comorbilidades de la población mexicana, la infección por SARS-CoV-2 representa un gran desafío y una "caja de pandora", por lo que no deberá descartarse la posibilidad de nuevos mecanismos fisiopatogénicos. Se podría sugerir la participación de SARS-CoV-2 si existiera coincidencia de infección en células testiculares que expresan los receptores de este virus.

\section{Agradecimientos}

Los autores agradecen a las autoridades y a la Coordinación de Investigación en Salud del Instituto Mexicano del Seguro Social, el apoyo durante el tiempo de cuarentena. A Tomás Hernández, por cumplir con su deber.

\section{Conflicto de intereses}

Los autores declaran no tener conflicto de intereses.

\section{Financiamiento}

Los autores no recibieron patrocinio para llevar a cabo este artículo.

\section{Responsabilidades éticas}

Protección de personas y animales. Los autores declaran que para esta investigación no se realizaron experimentos en seres humanos ni en animales. 
Confidencialidad de los datos. Los autores declaran que en este artículo no aparecen datos de pacientes.

Derecho a la privacidad y consentimiento informado. Los autores declaran que en este artículo no aparecen datos de pacientes.

\section{Referencias}

1. Huang C, Wang Y, Li X, Ren L, Zhao J, Hu Y, et al. Clinical features of patients infected with 2019 novel coronavirus in Wuhan, China. Lancet. 2020;395:497-506.

2. PubMed browser [Internet]. Bethesda (MD): U.S. National Library of Medicine. Sars cov 2, molecular biology; 2020. Disponible en: https:// pubmed.ncbi.nlm.nih.gov/?term=sars+cov+2 \%2C+molecular+biology

3. Wu F, Zhao S, Yu B, Chen YM, Wang W, Song ZG, et al. A new coronavirus associated with human respiratory disease in China. Nature. 2020:579:265-269.

4. Zhang $\mathrm{T}$, Wu Q, Zhang Z. Probable pangolin origin of SARS-CoV-2 associated with the COVID-19 outbreak. Curr Biol. 2020;30:1346-1351.

5. Andersen KG, Rambaut A, Lipkin WI, et al. The proximal origin of SARSCoV-2. Nat Med. 2020;26:450-452.

6. Khailany RA, Safdar M, Ozaslan M. Genomic characterization of a novel SARS-CoV-2. Gene Rep. 2020;19:100682. DOI: 10.1016/j.genrep.2020.100682

7. Baud D, Qi X, Nielsen-Saines K, Musso D, Pomar L, Favre G. Real estimates of mortality following COVID-19 infection. Lancet Infect Dis. 2020;S1473-3099:30195-X.

8. Pachetti M, Marini B, Benedetti F. et al. Emerging SARS-CoV-2 mutation hot spots include a novel RNA-dependent-RNA polymerase variant. J Transl Med. 2020;18:179

9. Kim D, Lee JY, Yang JS, Kim JW, Kim VN, Kim H. The architecture of SARS-CoV-2 transcriptome. Cell. 2020;181:1-8.

10. Wu YS, Lin WH, Hsu JT, Hsieh HP. Antiviral drug discovery against SARS-CoV. Curr Med Chem. 2006;13:2003-2020.

11. Ai T, Yang Z, Hou H, Zhan C, Chen C, Lv W, et al. Correlation of chest CT and RT-PCR testing in coronavirus disease 2019 (COVID-19) in China: A report of 1014 cases. Radiology. 2020;200642.

12. Center for Health Security [Internet]. Baltimore: Molecular-based tests for COVID-19. Johns Hopkins University; 2020

13. U.S. Food and Drug Administration [Internet]. Silver Spring (MD): Coronavirus (COVID-19) update: FDA authorizes first test for patient at-home sample collection; 2020.

14. Okba N, Muller M, Li W, Wang C, Geurts-van Kessel C, Corman V, et al. SARS-CoV-2 specific antibody responses in COVID-19 patients. medRxiv. 2020 Mar 20. DOI: 10.1101/2020.03.18.20038059

15. Amanat F, Nguyen T, Chromikova V, Strohmeier S, Stadlbauer D, McMahon $\mathrm{M}$, et al. A serological assay to detect SARS-CoV-2 seroconversion in humans. medRxiv.2020 Apr 16. DOI:/10.1101/2020.03.17.20037713

16. He X, Lau EHY, Wu P, Deng X, Wang J, Hao X, et al. Temporal dynamics in viral shedding and transmissibility of COVID-19. Nat Med. 2020;26:672-675.
17. Peng-Jia H, Look DC, Shi L, Hickey M, Pewe L, Netland J, et al. ACE2 receptor expression and severe acute respiratory syndrome coronavirus infection depend on differentiation of human airway epithelia. J Virol. 2005;79:14614-14621.

18. Wang K, Chen W, Zhou YS, Lian JQ, Zhang Z, Du P, et al. SARS-CoV-2 invades host cells via a novel route: CD147-spike protein. bioRxiv. 2020;3:14.

19. Hoffmann M, Kleine-Weber H, Schroeder S, Krüger N, Herrler T, Erichsen S, et al. SARS-CoV-2 cell entry depends on ACE2 and TMPRSS2 and is blocked by a clinically proven protease inhibitor. Cell. 2020;181:271-280.

20. Thul PJ, Lindskog C. The Human Protein Atlas: A spatial map of the human proteome. Protein Sci. 2018;27:233-244.

21. Wu C, Orozco C, Boyer J, Leglise M, Goodlae J, Batalov S, et al. BioGPS: An extensible and customizable portal for querying and organizing gene annotation resources. Genome Biol. 2009;10:R130.

22. Hui KPY, Cheung MC, Perera RAPM, Ng KC, Bui CBT, Ho JCW, et al. Tropism of the novel coronavirus SARS-CoV-2 in human respiratory tract: An analysis in ex vivo and in vitro cultures. Lancet Resp Med. 2020 Mar 25. DOI: $10.2139 /$ ssrn.3552870

23. Ding Y, He L, Zhang Q, Huang Z, Che X, Hou J, et al. Organ distribution of severe acute respiratory syndrome (SARS) associated coronavirus (SARS-CoV) in SARS patients: Implications for pathogenesis and virus transmission pathways. J Pathol. 2004;203:622-630.

24. Batlle D, Soler M, Sparks MA, Hiremath S, South AM, Welling PA, et al. Acute kidney injury in COVID-19: Emerging evidence of a distinct pathophysiology. J Am Soc Nephrol. 2020 May 04. DOI: 10.1681/ ASN.2020040419

25. Baig AM. Neurological manifestations in COVID-19 caused by SARSCoV-2. CNS Neurosci Ther. 2020 Apr 07. DOI: 10.1111/cns.13372

26. Lamers MM, Beumer J, van der Vaart J, Knoops K, Puschhof J, Breugem TI, et al. SARS-CoV-2 productively infects human gut enterocytes. Science. 2020 May 01. DOI: DOI: 10.1126/science.abc1669

27. Fox S, Akmatbekov A, Harbert JL, Li G, Brown JQ, Vander-Heide RS, et al. Pulmonary and cardiac pathology in Covid-19: The first autopsy series from New Orleans. medRxiv. 2020 Apr 10. DOl: 10.1101/2020.04.06.20050575

28. Rubin S, Eckhaus M, Rennick LJ, Bamford CG, Duprex WP. Molecular biology, pathogenesis and pathology of mumps virus. J Pathol. 2015;235:242-252.

29. Centers for Disease Control and Prevention [Internet]. Georgia: Hepatitis C; 2020. Disponible en: https://www.cdc.gov/hepatitis/hcv/index.htm

30. Nicoll MP, Proença JT, Efstathiou S. The molecular basis of herpes simplex virus latency. FEMS Microbiol Rev. 2012;36:684-705.

31. An J, Liao X, Xiao T, Qian S, Yuan J, Ye H, et al. Clinical characteristics of the recovered COVID-19 patients with re-detectable positive RNA test. medRxiv. 2020 Mar 30. DOI: 10.1101/2020.03.26.20044222

32. Broad Institute [Internet]. Zhang F, Abudayyeh OO, Gootenberg JS. A protocol for detection of COVID-19 using CRISPR diagnostics; 2020. Disponible en: https://www.broadinstitute.org/files/publications/special/ COVID-19\%20detection\%20(updated).pdf

33. Wu Y Guo C Tang L, et al. Prolonged presence of SARS-CoV-2 viral RNA in faecal samples. Lancet Gastroenterol Hepatol. 2020;5:434-435.

34. Wölfe R, Corman V, Guggemos W, Seilmaier M, Zange S, Müller MA, et al. Virological assessment of hospitalized patients with COVID-2019. Nature. 2020;581:465-469.

35. Fan C, Li K, Ding Y, Lu WL, Wang J. ACE2 expression in kidney and testis may cause kidney and testis damage after 2019-nCoV infection. medRxiv. 2020 Feb 13. 10.1101/2020.02.12.20022418 